\title{
Pollination networks from natural and anthropogenic-novel communities show high structural similarity
}

\author{
Sérgio Timóteo ${ }^{1}$ (1) . Catherine J. O'Connor ${ }^{1,2} \cdot$ Francisco A. López-Núñez $^{1}$. José M. Costa ${ }^{1}$ António C. Gouveia ${ }^{1,3}$. \\ Ruben H. Heleno'
}

Received: 30 March 2018 / Accepted: 28 September 2018

○) Springer-Verlag GmbH Germany, part of Springer Nature 2018

\begin{abstract}
The Anthropocene is marked by an unprecedented homogenisation of the world's biota, confronting species that never co-occurred during their evolutionary histories. Interactions established in these novel communities may affect ecosystem functioning; however, most research has focused on the impacts of a minority of aggressive invasive species, while changes inflicted by a less conspicuous majority of non-invasive alien species on community structure are still poorly understood. This information is critical to guide conservation strategies, and instrumental to advance ecological theory, particularly to understand how non-native species integrate in recipient communities and affect the interactions of native species. We evaluated how the structure of 50 published pollination networks changes with the proportion of alien plant species and found that network structure is largely unaffected. Although some communities were heavily invaded, the proportion of alien plant species was relatively low (mean $=10 \%$; max. $=38 \%$ ). We further characterized the pollination network in a botanic garden with a plant community dominated by non-invasive alien species $(85 \%)$. We show that the structure of this novel community is also not markedly different from native-dominated communities. Plant-pollinator interactions revealed no obvious differences regarding plant origin (native vs. alien) or the native bioregion of the introduced plants. This overall similarity between native and alien plants is likely driven by the contrasting patterns of invasive plants (promoting generalism), and non-invasive aliens, suggested here to promote specialization.
\end{abstract}

Keywords Biological homogenisation $\cdot$ Biological invasions $\cdot$ Botanic garden $\cdot$ Alien plants $\cdot$ Novel communities

\section{Introduction}

The intensification of international trade has resulted in an unprecedented reshuffling of species across national and continental borders with the concomitant homogenisation

Communicated by Monica Geber.

Electronic supplementary material The online version of this article (https://doi.org/10.1007/s00442-018-4281-5) contains supplementary material, which is available to authorized users.

Sérgio Timóteo

stimoteo@gmail.com

1 Department of Life Sciences, Centre for Functional Ecology (CFE-UC), University of Coimbra, Coimbra, Portugal

2 Cardiff School of Biosciences, Cardiff University, Cardiff, UK

3 Botanic Garden of the University of Coimbra, Coimbra, Portugal of the world's biota (McKinney and Lockwood 1999; Olden et al. 2006; Devictor et al. 2010). Accordingly, the progressive taxonomic, genetic, and functional similarity of communities in response to the rapid translocation of species among previously isolated bioregions is currently a central concern in conservation (Olden et al. 2006; Smart et al. 2006; Barnosky et al. 2012). Plants, in particular, are often introduced into non-native ranges-alien species, either intentionally for their agricultural or ornamental value, or accidentally (Potts et al. 2010). Many of these species can overcome the biotic and abiotic barriers that limit their survival and reproduction in their recipient communities, and some can rapidly spread in the new ranges to become invasive, i.e. "winners" (sensu McKinney and Lockwood 1999), outcompeting many native species ("losers") (Vilà et al. 2009; Richardson 2010). Community-level studies showed that this replacement might lead to a reduction in plant species richness that can ripple through food-webs, causing further simplification of entire communities (e.g. Heleno et al. 2009; López-Núñez 
et al. 2017), threatening community stability and ecosystem services (Richardson et al. 2000a; Traveset and Richardson 2006). Many of these changes have been recently highlighted by implementing a network/food web approach to explore the interplay between community composition, structure, and functioning (e.g. Heleno et al. 2014; Tylianakis and Morris 2017). Overall, the invasion of plant-animal mutualistic networks seems to increase the level of generalism of interaction networks as these become dominated by generalist alien species (Aizen et al. 2008; Tylianakis and Morris 2017). Importantly, however, most of these studies are largely restricted to the impacts of only one or a few dominant invasive species, such as Impatiens glandulifera in the UK (Lopezaraiza-Mikel et al. 2007), Carpobrotus affine and Opuntia stricta in Spain (Bartomeus et al. 2008), Opuntia spp. in the Canaries and Balearics (Padrón et al. 2009), and others (e.g. Aizen et al. 2008; Vilà et al. 2009; Albrecht et al. 2014). Even if some of these studies monitored highly invaded sites, the focus was on the impacts of one or a few aggressive invasive species (e.g. Stouffer et al. 2014; Albrecht et al. 2014; Kaiser-Bunbury et al. 2017). However, it is estimated that only $11 \%$ of the alien plant species in Europe are invasive, which fits the informal tens-rule by which only one in 10 introduced species becomes invasive (Williamson 1993; Vilà et al. 2010). While understandable, the emphasis put on documenting the impacts of invasive species is in sharp contrast with the relative small proportion of all alien species that actually have a documented invasive behaviour (Williamson 1993; Vander Zanden 2005; Vilà et al. 2010), thus generating a bias towards invasive species in the literature. For example, in the studies of Traveset et al. (2013), and Memmott and Waser (2002), which look at the impact of alien plants, only $5 \%$ and $12 \%$ of the plant species on invaded communities are actually introduced to the Galapagos and the United States, respectively. These studies are indeed highly informative regarding the impacts of invasive alien plant species (e.g. Albrecht et al. 2014). However, they tend to neglect the potential impacts of a vast majority of non-invasive alien species that slowly naturalize in the wild without significant spread (Richardson et al. 2000b; Olden et al. 2006). Consequently, these studies might not fully capture the effects of biotic homogenisation resulting from direct or indirect human disturbance (e.g. Lurgi et al. 2012). Understanding the interaction patterns that characterize novel communities, i.e. those formed by species that do not share a common evolutionary history (Hobbs et al. 2006), is essential to evaluate community resilience and the capacity of these communities to continue to delivery key ecosystem services (Razanajatovo et al. 2015; Hui et al. 2016; Le Roux et al. 2017). In this context, botanical gardens represent an invaluable experimental ground for comparative and community-wide studies as they host a wide range of species from different origins, growing under the same climatic and ecological conditions (Primack and Miller-Rushing 2009; Razanajatovo et al. 2015, 2018).

Here, we first evaluate if the proportion of alien plant species present in 50 quantitative pollination networks available in the literature result in any consistent change on network structure. Changes in community structure resulting from the incorporation of alien species may result in the redistribution of links among species (Aizen et al. 2008; Grass et al. 2013). We hypothesise that the integration of alien plant species will tend to increase network connectivity as alien plant species tend to produce many large and conspicuous flowers -with abundant nectar and pollen rewards (Chittka and Schürkens 2001; Morales and Aizen 2006; van Kleunen et al. 2018), thus attracting a large assembly of pollinators (Aizen et al. 2008; Albrecht et al. 2014). Second, we reconstruct the pollination network of the highly anthropogenic setting of a botanical garden in Portugal to explore if the structure of this novel community significantly differs from the structure of spontaneous communities dominated by native plant species. Finally, we aimed to investigate whether native and alien plant species in this novel community consistently differ in the interaction patterns established with the pollinator fauna, and if plant species native from different global biogeographic regions (hereafter bioregions) diverge in their visitation patterns. We expect that alien species will tend to be visited by a greater number of pollinators and a higher specialization of native species, and that Holarctic plants will differ in the interaction patterns from the those observed for species from the remaining bioregions.

\section{Methods}

\section{Is community structure affected by the incorporation of alien plant species?}

To evaluate how the structure of pollination networks is affected by alien species we calculated eight networklevel descriptors for 50 quantitative plant-pollinator networks available in the ecological literature (Table 1, and Supplementary references). As independent estimates of plant species abundance are rarely available we used the proportion of alien plant species in the network as a proxy of alien plant integration (Traveset et al. 2016). Alternative measures could include the proportion of insect visits to alien plant species (\% of the matrix marginal sums of alien plants), although such a metric would be largely constrained by species visitation patterns and, therefore, a result of network structure (Dormann et al. 2017). Thus, the proportion of alien species provides in our view a more independent benchmark to explore the consequences of all alien plants regardless of their local abundance and visitation patterns. 
Table 1 Study location, pollination network size and number of alien plant species from the literature (full references in the ESM)

\begin{tabular}{|c|c|c|c|}
\hline Study location & $\begin{array}{l}\text { Network size (plant sp. } \times \text { ani- } \\
\text { mal sp.) }\end{array}$ & $\begin{array}{l}\text { Number of alien plant spe- } \\
\text { cies }(\%)\end{array}$ & References \\
\hline Berchtesgaden NP, Germany & $121 \times 410$ & $0(0.0)$ & Benadi et al. (2013) \\
\hline Nahuel Huapi NP, Argentina & $41 \times 90$ & $2(14.3)$ & Vázquez and Simberloff (2002) \\
\hline Kosciusko NP, Australia & $41 \times 83$ & $2(4.9)$ & Inouye and Pyke (1988) \\
\hline Avon Gorge, UK & $64 \times 174$ & $7(10.9)$ & Carvalheiro et al. (2008) \\
\hline Bristol, UK & $25 \times 79$ & $0(0.0)$ & Memmott (1999) \\
\hline Bristol, UK & $23 \times 147$ & $1(4.3)$ & Lopezaraiza-Mikel et al. (2007) \\
\hline Duke forest, North Carolina, USA & $13 \times 47$ & $0(0.0)$ & Motten (1986) \\
\hline Cap de Creus NP, Spain & $32 \times 81$ & $7(20.4)$ & Bartomeus et al. (2008) \\
\hline University of Wurzburg, Germany & $56 \times 257$ & $4(7.1)$ & Junker et al. (2013) \\
\hline Hestehaven, Denmark & $28 \times 82$ & $8(28.6)$ & Olesen (unpublished data) \\
\hline Norwood farm, UK & $47 \times 241$ & $9(19.1)$ & Pocock et al. (2012) \\
\hline Ottawa, Canada & $13 \times 24$ & $0(0.0)$ & Small (1982) \\
\hline Nahuel Huapi NP, Argentina & $27 \times 111$ & $10(35.8)$ & Aizen et al. (2008) \\
\hline Western Sahara & $12 \times 82$ & $1(8.3)$ & Trøjelsgaard et al. (2015) \\
\hline Cairngorms NP, UK & $28 \times 162$ & $1(3.6)$ & Devoto et al. (2012) \\
\hline Latnjajaure, Abiskoosta, Sweden & $23 \times 118$ & $0(0.0)$ & Elberling and Olesen (1999) \\
\hline Hickling, Norfolk, UK & $17 \times 61$ & $0(0.0)$ & Dicks et al. (2002) \\
\hline Shelfanger, Norfolk, UK & $16 \times 36$ & $0(0.0)$ & Dicks et al. (2002) \\
\hline Ilê aux Aigrettes, Mauritius & $14 \times 13$ & $5(8.6)$ & Olesen et al. (2002) \\
\hline Lake Hazen, Ellesmere Is., Canada & $29 \times 81$ & $0(0.0)$ & Hocking (1968) \\
\hline Lake Hazen, Ellesmere Is., Canada & $30 \times 114$ & $0(0.0)$ & Kevan (1970) (PhD thesis) \\
\hline Black River Gorge NP, Mauritius & $58 \times 100$ & $5(8.6)$ & Kaiser-Bunbury et al. (2009) \\
\hline Flores Is., Azores & $10 \times 12$ & $3(30.0)$ & Olesen et al. (2002) \\
\hline Las Conchas, Graciosa, Canary Is. & $25 \times 61$ & $0(0.0)$ & Castro-Urgal and Traveset (2014) \\
\hline Caletón Blanco, Lanzarote, Canary Is. & $18 \times 60$ & $1(5.6)$ & Castro-Urgal and Traveset (2014) \\
\hline Son Bosc, Mallorca, Balearics & $67 \times 123$ & $2(3.0)$ & Castro-Urgal and Traveset (2014) \\
\hline Cala Mesquida, Mallorca, Balearics & $42 \times 118$ & $0(0.0)$ & Castro-Urgal and Traveset (2014) \\
\hline Puig Major, Mallorca, Balearics & $54 \times 183$ & $0(0.0)$ & Tur (2015) (PhD thesis) \\
\hline Nakaikemi, Tsuruga, Japan & $64 \times 187$ & $3(4.7)$ & Kato and Miura (1996) \\
\hline Mt Kushigata, Japan & $90 \times 356$ & $1(1.1)$ & Kato et al. (1993) \\
\hline Mt Yufu, Kyusyu, Japan & $99 \times 294$ & $4(4.0)$ & Yamazaki and Kato (2003) \\
\hline Melville Is., Canada & $11 \times 18$ & $0(0.0)$ & Mosquin and Martin (1967) \\
\hline Fernandina Is., Galapagos, Ecuador & $18 \times 60$ & $0(0.0)$ & Traveset et al. (2013) \\
\hline Pinta Is., Galapagos, Ecuador & $21 \times 76$ & $0(0.0)$ & Traveset et al. (2013) \\
\hline Santiago Is., Galapagos, Ecuador & $24 \times 69$ & $2(8.3)$ & Traveset et al. (2013) \\
\hline San Cristobal Is., Galapagos, Ecuador & $21 \times 93$ & $3(14.3)$ & Traveset et al. (2013) \\
\hline Santa Cruz Is., Galapagos, Ecuador & $23 \times 76$ & $1(4.3)$ & Traveset et al. (2013) \\
\hline Kyoto City, Japan & $113 \times 314$ & $43(38.1)$ & Kakutani et al. (1990) \\
\hline Uummannaq Is., Greenland & $17 \times 26$ & $1(2.6)$ & Lundgren and Olesen (2005) \\
\hline Amami-Ohsima Is., Ryukyu, Japan & $110 \times 609$ & $4(3.6)$ & Kato (2000) \\
\hline Jamaica, Carabbean & $12 \times 43$ & $2(6.9)$ & Ingversen (2006) (MSc thesis) \\
\hline Dominica, Caribbean & $31 \times 43$ & $1(3.2)$ & Ingversen (2006) (MSc thesis) \\
\hline Gran Canaria, Canary Is. & $12 \times 73$ & $0(0.0)$ & Trøjelsgaard et al. (2015) \\
\hline La Gomera, Canary Is. & $15 \times 73$ & $0(0.0)$ & Trøjelsgaard et al. (2015) \\
\hline Fuerteventura, Canary Is. & $9 \times 74$ & $0(0.0)$ & Trøjelsgaard et al. (2015) \\
\hline Teno, Tenerife, Canary Is. & $19 \times 89$ & $0(0.0)$ & Trøjelsgaard et al. (2015) \\
\hline Fasnia, Tenerife, Canary Is. & $16 \times 92$ & $0(0.0)$ & Trøjelsgaard et al. (2015) \\
\hline Fårö, Baltic Is., Sweden & $34 \times 88$ & $2(5.9)$ & Johansson (2012) \\
\hline Gotska Sandon, Baltic Is., Sweden & $44 \times 160$ & $2(4.5)$ & Wallin (2011) (MSc thesis) \\
\hline
\end{tabular}


Table 1 (continued)

\begin{tabular}{llll}
\hline Study location & $\begin{array}{l}\text { Network size (plant sp. } \times \text { ani- } \\
\text { mal sp.) }\end{array}$ & $\begin{array}{l}\text { Number of alien plant spe- } \\
\text { cies }(\%)\end{array}$ & References \\
\hline Hierro, Canary Is. & $11 \times 62$ & $0(0.0)$ & $\begin{array}{l}\text { Trøjelsgaard et al. (2015) } \\
\text { This study }\end{array}$ \\
Coimbra, Portugal & $132 \times 176$ & & (2) \\
\hline
\end{tabular}

Because interaction frequency has been quantified differently across studies (e.g. number of visits, visitation rate), all matrices were standardized by dividing its interaction weights by the lowest non-zero interaction weight in the matrix and rounded it to nearest integer. This transformation converts interactions in each matrix to multiples of the lowest link weight. The following descriptors were evaluated: (1) mean number of links per species; (2) weighted connectance, the link density divided by the total number of species present in the network (Tylianakis et al. 2007); (3) weighted nestedness (WINE_-Weighted Interaction Nestedness Estimator), measuring the extent to which the interactions are hierarchically arranged around a core of generalist interactions (Galeano et al. 2009); (4) network specialisation $\left(\mathrm{H}_{2}^{\prime}\right)$, a discriminative measure of network selectiveness (Blüthgen et al. 2006); (5) pollinator robustness, the extent to which the pollinator community is resilient to the random loss of plant species; and (6) plant robustness, the extent to which the plant community is resilient to the random loss of pollinators (Memmott et al. 2004).

Because several network-level descriptors are not independent from network size and sampling effort (Fründ et al. 2016), we compared community structure by means of null model-corrected network descriptors, which allow for comparisons across networks based on the relative departure of the observed structure from that predicted by a null model expectation based on random interactions
(Thebault and Fontaine 2010; Schleuning et al. 2012; Costa et al. 2015). This was done by calculating the difference between each network descriptor and those from 1000 randomized networks obtained with Patefield's null model (Patefield 1981), which reshuffles interactions while constraining species richness and the number of interactions per species (Dormann et al. 2008), and dividing it by the mean of the randomized networks.

To assess the effect of the proportion of alien species on the number of links per species and weighted connectance we used a Generalized Linear Models (GLM) with Gamma and Gaussian errors, respectively, with the $\mathrm{R}$ function $\mathrm{g} \operatorname{lm}($ ). To account for the presence of extreme values and heteroscedasticity when exploring the effects on nestedness, network specialization, insect robustness, and plant robustness we used a robust generalized linear model with Gamma errors. Robust regressions have the advantage of down-weighting the influence of outliers and being more robust to heterogeneous variance than standard regressions, allowing the effect of variables and their direction not to be affected by a few highly influential points (Cantoni and Ronchetti 2001, 2006). This procedure was implemented with the function glmrob() from the $\mathrm{R}$ package robustbase 0.92-8 (Rousseeuw et al. 2017). All response variables were transformed to meet the assumptions of the respective models and achieve a better fit (see Table 2 for details).

Table 2 Effects of the proportion of alien species on network structure descriptors explored by GLMs and robust GLMs

\begin{tabular}{|c|c|c|c|c|c|c|}
\hline & Links per species & $\begin{array}{l}\text { Weighted con- } \\
\text { nectance }\end{array}$ & Weighted nestedness & $\begin{array}{l}\text { Network specializa- } \\
\text { tion }\end{array}$ & Pollinator robustness & Plant robustness \\
\hline Transformation & $-y$ & & $-(y-1)$ & $\log (y)$ & $-y$ & $-y$ \\
\hline Model & GLM & LM & Robust GLM & Robust GLM & Robust GLM & Robust GLM \\
\hline Error family & Gamma & & Gamma & Gamma & Gamma & Gamma \\
\hline Link function & Identity & & Inverse & Inverse & Inverse & Inverse \\
\hline Intercept & 48.509 & 53.051 & 0.037 & 0.151 & 0.110 & 0.066 \\
\hline (SE) & (3.360) & (2.389) & $(0.004)$ & $(0.004)$ & $(0.012)$ & $(0.009)$ \\
\hline$p$ & $<2 \mathrm{e}-16^{* * *}$ & $<2 \mathrm{e}-16^{* * *}$ & $<2 \mathrm{e}-16^{* * *}$ & $<2 \mathrm{e}-16^{* * *}$ & $<2 \mathrm{e}-16^{* * *}$ & $2 \mathrm{e}-13^{* * *}$ \\
\hline$\%$ Aliens & 0.299 & 0.065 & -0.0001 & -0.0001 & -0.001 & -0.0004 \\
\hline (SE) & $(0.309)$ & $(0.194)$ & $(0.0003)$ & $(0.0003)$ & $(0.001)$ & $(0.001)$ \\
\hline$p$ & 0.338 & 0.737 & 0.817 & 0.821 & 0.564 & 0.527 \\
\hline
\end{tabular}

All descriptors were corrected against a null model based on the Patefield's algorithm. $P$ values were derived with a $t$ test for links per species and weighted connectance, and with a $z$ score test for the remaining descriptors. $* p<0.1 ; * * p<0.05$;** $p<0.01$ 


\section{How does a novel community differ from spontaneous communities dominated by native plant species?}

To assess the structural differences between a highly anthropogenic novel community and those dominated by native plant species, we reconstructed the plant-pollinator network of the Botanic Garden of the University of Coimbra, central Portugal $\left(40^{\circ} 12^{\prime} \mathrm{N}, 8^{\circ} 25^{\prime} \mathrm{W}\right.$, ESM Fig. S1). The garden is primarily host to species of medical interest and ornamental alien flora, many of which originated from former Portuguese colonies around the world, including Angola and Mozambique (Africa), Brazil (South America), and across Asia, with selected representative species from all the main branches of the plant phylogenetic tree distributed in flower beds, and active maintenance is kept to the minimum necessary. The site has a Mediterranean climate influence with mild-humid winters and hot-dry summers.

We recorded flower-visitation interactions by conducting timed censuses to focal flowers (Castro-Urgal et al. 2012), between 9:00 $\mathrm{h}$ and 19:30 $\mathrm{h}$ during favourable weather conditions from 28-Oct-2016 to 20-May-2017. We conducted at least $15 \mathrm{~min}$ of observations on each plant species twice per week during their complete flowering season, recording all contacts of flying animals with the reproductive organs of open flowers. Although pollination effectiveness was not experimentally confirmed, we only recorded visitors that directly contacted with the stigmas or the anthers, and hereafter we refer to them as pollinators for simplicity. Overall, we accumulated $255 \mathrm{~h}$ of visitation census, which is within the range of the sampling effort of the networks retrieved from the literature $($ mean $=142 \mathrm{~h}$; $\min .=18 \mathrm{~h}$; max. $=300 \mathrm{~h}$ ); the observation time of each plant species being proportional to its abundance and to the duration of its flowering period, so that rare interactions are not oversampled. Initially voucher specimens of all pollinating insects were collected and identified by expert taxonomists to lowest possible taxonomic level. To minimize the disturbance of the local pollinator fauna, on subsequent visits by visually similar insects, these were captured, photographed, and immediately released on site, being latter identified based on the voucher specimens. Flower abundance was estimated by weekly floral surveys, counting all open flowers of each species along three linear transects of $200 \mathrm{~m} \times 10 \mathrm{~m}$. We considered flower units as separate entities if the distance between them required the pollinator to fly from one unit to the other (e.g. Carvalheiro et al. 2008).

All pairwise interactions between plants and pollinators were organised into an interaction matrix, where each pairwise interaction was quantified in terms of flower visitation rate, i.e. number of visits/number of open flowers/time, which allows a realistic representation of the community structure (Castro-Urgal et al. 2012). The same network standardization and null model corrected network descriptors used in the previous section were applied to the Botanic Garden network. Network descriptors from this network were then compared to those from the literature and significant differences were inferred whenever a descriptor of the novel networks lay outside the 95th percentile range of the corresponding descriptor on the reference networks.

\section{Do native and alien plant species differ in their pollinator visitation patterns?}

To look for differences in interactions established by different plant groups, we characterized all plant species according to their origin, i.e. native or alien to Portugal, and according to their native bioregion (Cox 2001). Bioregions define areas with unifying geographic features and marked by broad similarities in their flora and fauna (e.g. de Buffon 1761; von Humboldt 1816; Cox 2001). Plant species were assigned to a bioregion based on the online databases Global Biodiversity Information Facility (GBIF 2017) and World Checklist of Selected Plant Families (WCSP 2017). For each of these plant species, we then calculated three widely used descriptors of species-level interaction patterns: (1) plant degree (or linkage level), the number of pollinator species visiting each plant; (2) plant species strength, a measure of plant species' importance for the overall pollinator community; and (3) plant specialization index $\left(d^{\prime}\right)$, describing the level of plant selectiveness for pollinators as departing from an expected visitation frequency based exclusively on species abundances (Blüthgen et al. 2006). The effect of plant origin and bioregion on species-level descriptors was explored with independent (GLM) with negative binomial, Gamma and Gaussian errors, respectively, using the function $\operatorname{glm}($ ) available from software R 3.3.3 (R Development Core Team 2017). To meet the assumption of normality and homoscedasticity, specialisation d' was square root transformed. Pairwise differences were assessed using Tukey tests, with R's multcomp package (Hothorn et al. 2008).

All species- and network-level descriptors were calculated with the R package bipartite 2.08 (Dormann et al. 2009; Dormann 2011).

\section{Results}

\section{Is community structure affected by the incorporation of alien plant species?}

The number of plant species in the 50 networks retrieved from the literature varied between 22 and $719($ mean $=158)$, and the proportion of alien plant species between $0 \%$ (i.e. all plants being native) and $38 \%$ (mean $=7 \%$, median $=12 \%$; (Table 1). Contrary to our expectations, we found no 
significant effect of the proportion of alien plant species on any network descriptor ( $p>0.34$ for all descriptors; Fig. 1, Table 2).

\section{How does a novel community differ from spontaneous communities dominated by native plant species?}

Overall, we recorded 17,206 visits between 176 pollinators species and 132 plant species in the novel community of the botanical garden (Fig. 2). Most plants (85\%) were identified to the species level, and the remainder (15\%) to the genus level: $46 \%$ of the pollinators were identified to the species level, and the remainder were grouped into morphospecies within the lowest possible taxonomical level: genus (30\%), family (17\%), or order (7\%) (ESM Fig. S2). We recorded 9 orders of insects and a single bird species (blue tit, Cyanistes caeruleus), visiting flowers for pollen or nectar.

Most of the censused plant species were alien (85\%, 112 species), and most of them were intentionally planted and cultivated in the garden for several decades, and the remaining 20 plant species (15\%) were native. Nevertheless, the structure of the pollination network in this novel community is very similar to that of spontaneous communities reported in the literature, with all metrics falling within the 95th percentile range of the published networks (Fig. 1). a)

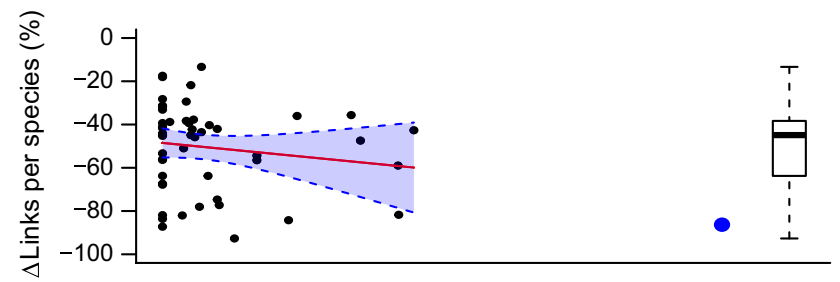

c)

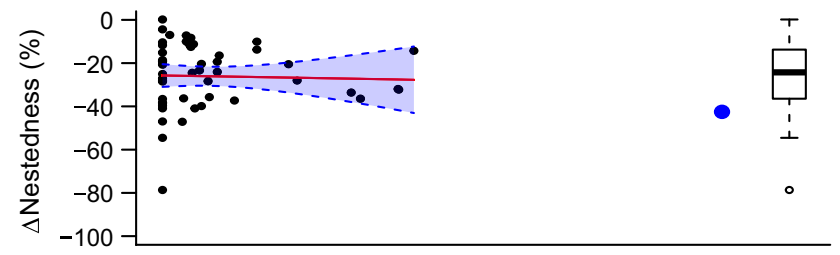

e)

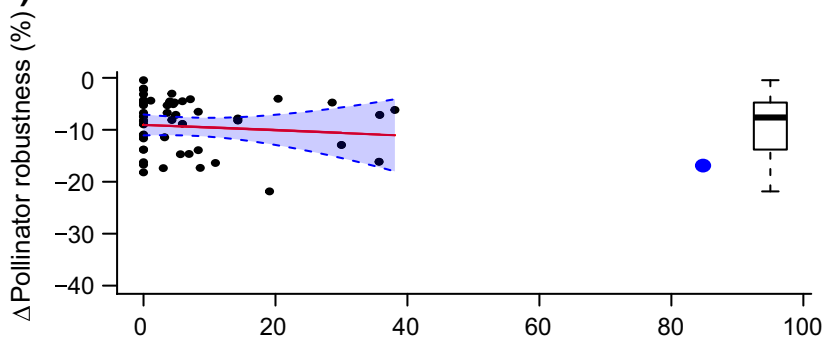

b)

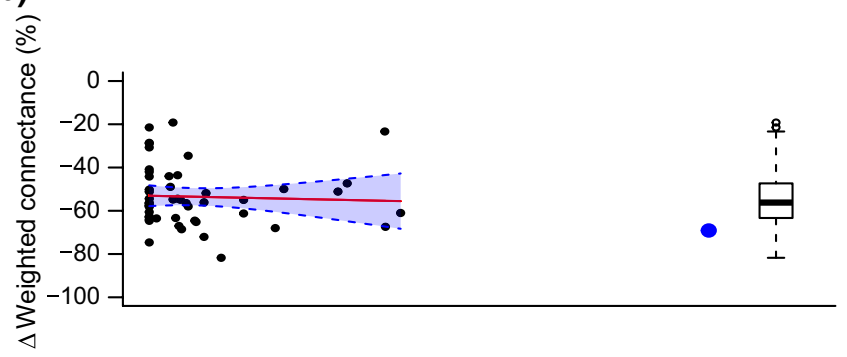

d)

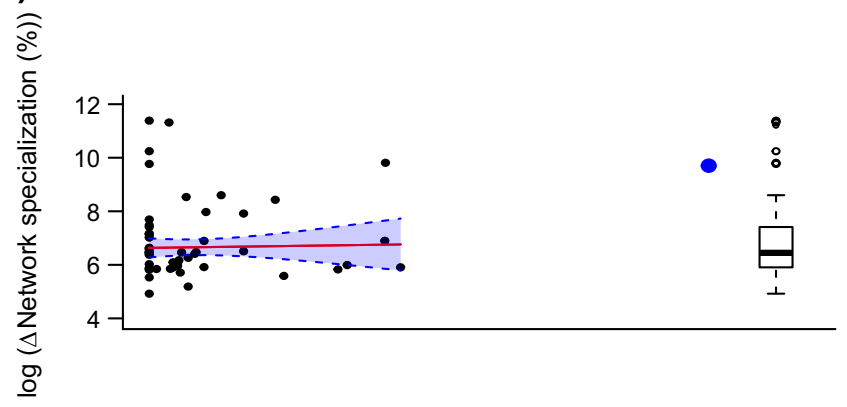

f)

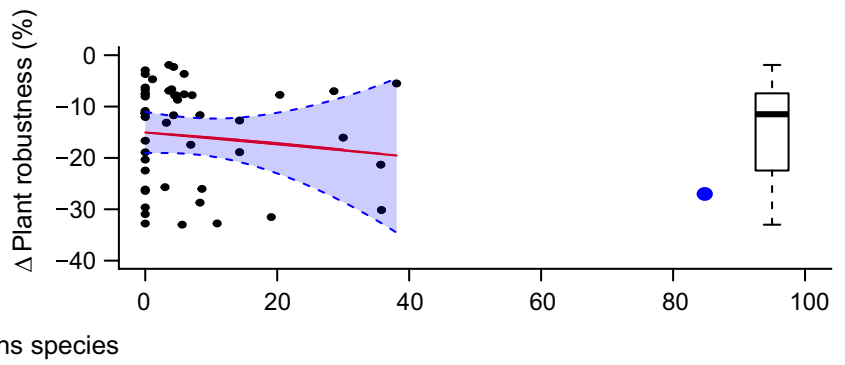

Fig. 1 Effect of the proportion of alien plant species on six network structure descriptors. Changes on each descriptor are considered in relation to the deviance of null model expectations to account for different network sizes (see "Methods"). Communities retrieved from the scientific literature are depicted in black, and the highly anthropogenic novel community of the Botanic Garden of the University of Coimbra-Portugal, in blue. The red line indicates the back-transformed fitted values of the regression and the shaded area represents the $95 \%$ confidence interval of the regression. The boxplots on the right represent the distribution of the values of each descriptor for the 50 published networks, regardless of their level of invasion. Colour version of this figure is available online 


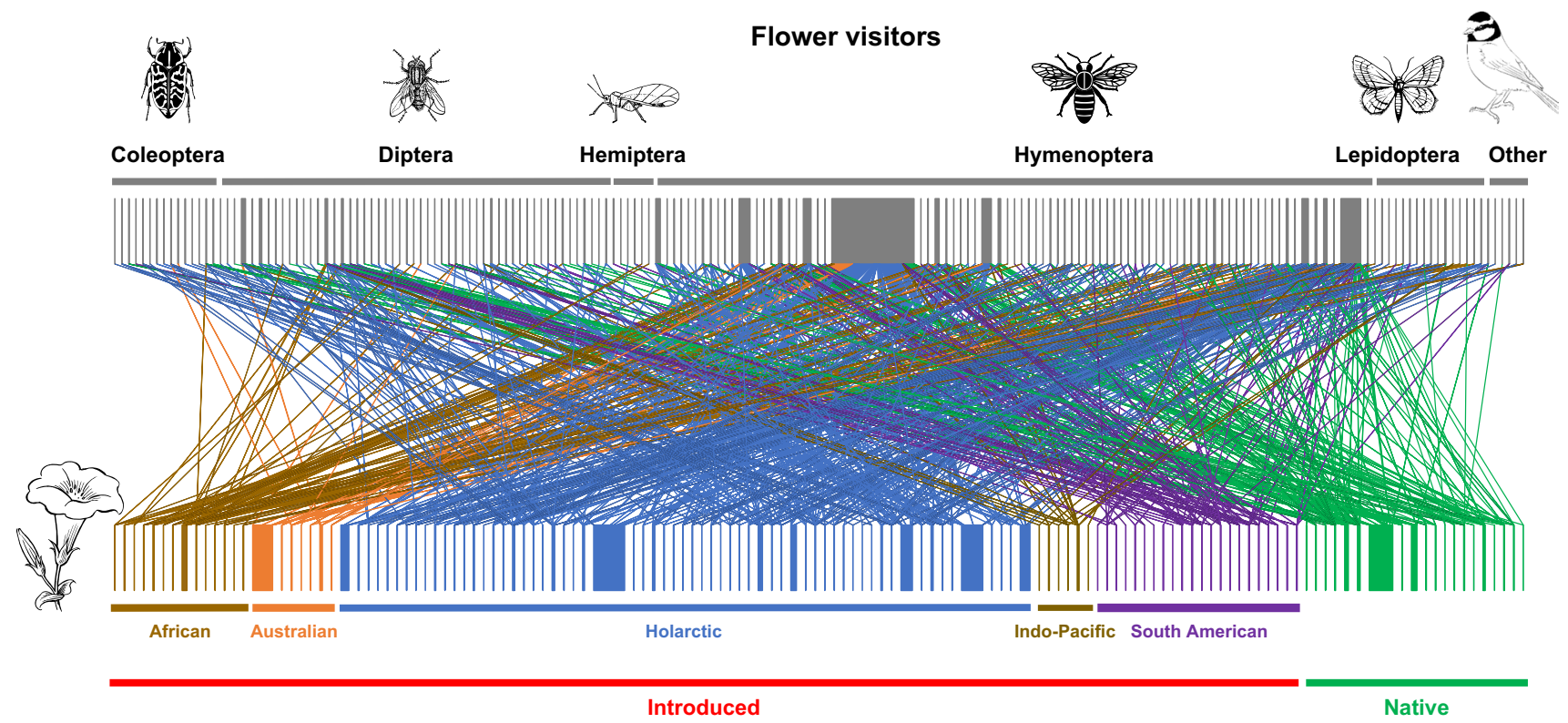

Fig. 2 Quantitative plant visitation network of the Botanic Garden of the University of Coimbra, Portugal. The network represents the interactions between 176 pollinators and 132 plant species and the width of each interaction is proportional to the number of visits/

\section{Do native and alien plant species differ in their pattern of interaction with pollinators?}

The alien species present in the botanical garden are native to the Holarctic (48\%, 63 species), South America (17\%, 22 species), Africa (10\%, 14 species), Australia (5\%, 7 species), and the Indo-Pacific (5\%, 6 species). The main pollinators were Hymenoptera, with respect to both species richness (45\%) and interaction frequency (87\%), followed by Diptera (31\% and $11 \%$, respectively). Apis mellifera was the most frequently recorded pollinator species with 6142 visits recorded (36\% of the total) and was also the most generalist, visiting the flowers of 67 plant species (50\% of all plants in the network; Fig. 1). On average, each pollinator species visited 4.6 plant species ( $\operatorname{Min}=1$; Max $=67$ ), which in turn received, on average, visits from 6.1 pollinator species (Min $=1 ; \operatorname{Max}=29$ ). We found no significant differences (all Tukey test, $p>0.18$ ) between alien and native plant species regarding the richness of pollinators (Fig. 3a; GLM: $\chi^{2}=1.37, d f=1 ; p=0.24$ ), specialisation d' (Fig. 3c; LM: $\chi^{2}=0.11, d f=1 ; p=0.07$ ), or plant species strength (Fig. 3e; GLM: $\left.\chi^{2}=0.72, d f=1 ; p=0.55\right)$. Similarly, we found no consistent differences (all Tukey test, $p>0.11$ ) between the interaction patterns established by plants from different bioregions regarding their number of pollinators (Fig. 3b; GLM: $\chi^{2}=11.30, d f=4 ; p=0.02$ ), specialisation $d^{\prime}$ (Fig. 3d; LM: $\chi^{2}=0.05, d f=4 ; p=0.82$ ), or species strength (Fig. 3f; GLM: $\left.\chi^{2}=15.27, d f=4 ; p=0.07\right)$. flower/minute. Network based on $255 \mathrm{~h}$ of direct observations to flowers between November 2016 and May 2017. Species identities provided in ESM Fig. S2. Colour version of this figure is available online

\section{Discussion}

Despite the large body of knowledge documenting the negative effects of invasive alien species on biodiversity and on community structure, there is still very little information regarding the effects on non-invasive alien plants, which form the largest component of species naturalized outside their native ranges worldwide. Contrary to our hypothesis, we did not detect any consistent effect of the proportion of alien plant species on the structure of published pollination networks. Additionally, we did not detect any major deviation between the trends found for the structure of previously published networks dominated by native plants $(<38 \%$ alien species) and a highly anthropogenic novel community from the Botanic Garden of the University of Coimbra, which to the best of our knowledge, corresponds to the largest proportion of alien plant species reported for any pollination network to date (85\%). Instead, the structure of this novel community network lies completely within the observed structure of native-dominated networks. Thus, the novel community was not more connected than the reference networks as initially expected, and no consistence trends were found for most descriptors, namely connectance, links per species, nestedness, and network robustness. If anything, the data could suggest a slight trend for higher network specialization; however, having data from only one novel network precludes any generalization on this matter. Contrary to our expectations, pollinators exhibited no evident preferences 
a)

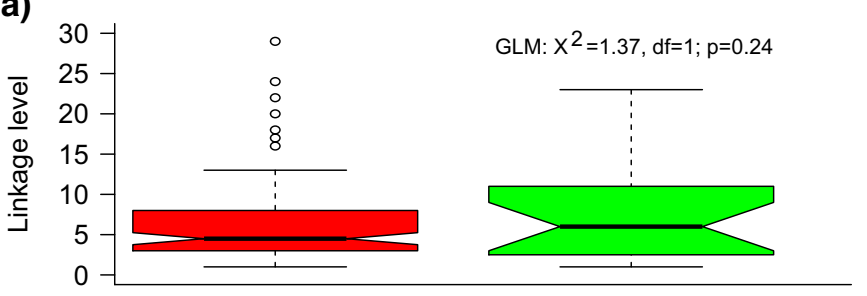

c)

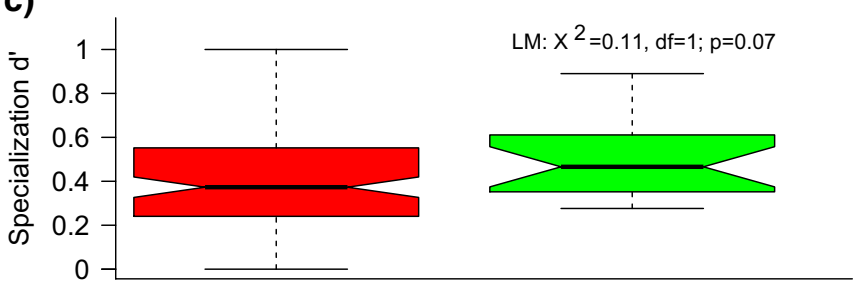

e)

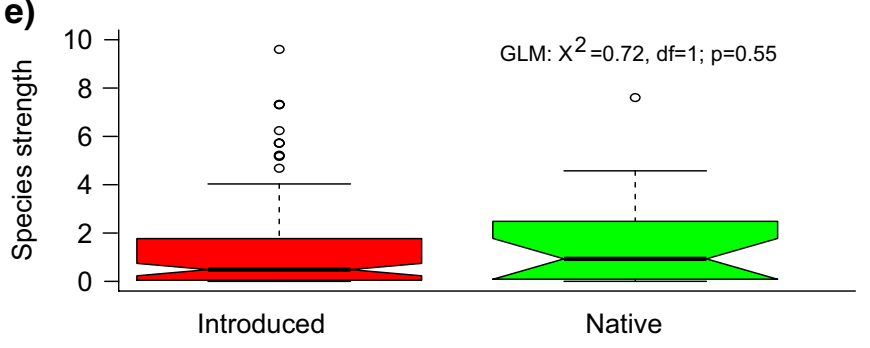

b)

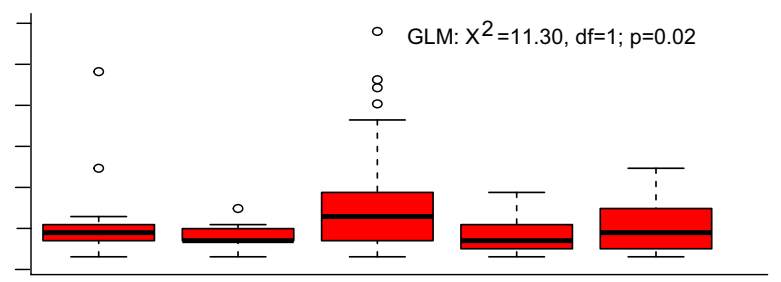

d)

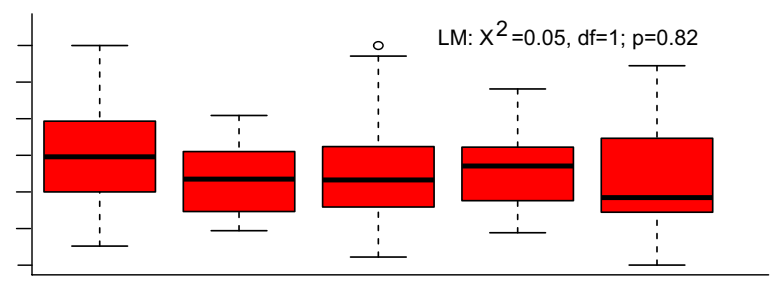

f)

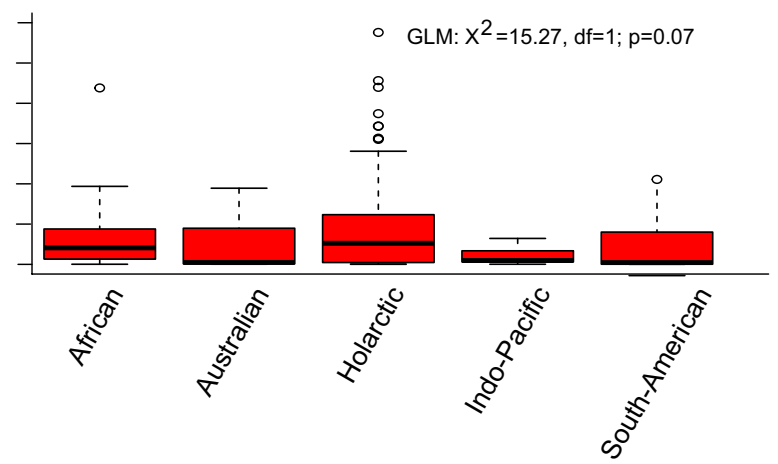

the $\chi^{2}$ tests report the deviance of the final model against that of a null model. Colour version of this figure is available online

2014). Notwithstanding, even when considering a highly anthropogenic novel community formed by $85 \%$ of alien plant species (more than tenfold the average proportion of alien species in the published networks and twice its maximum), a remarkable similarity still exists compared to what would be expected based on the trajectory of the known communities (Fig. 1). The apparent trend for a slightly higher overall specialization in our novel community might be counter-intuitive as most alien plants are frequently associated with high generalism (Aizen et al. 2008; Albrecht et al. 2014). This divergence can be driven by a traditionally stronger focus on alien species with a clear invasive behaviour (e.g. Lopezaraiza-Mikel et al. 2007; Bartomeus et al. 2008; Heleno et al. 2009). However, it can also result from opposing effects of invasive plants, generally assumed to promote generalism, and non-invasive alien plants, which might promote network specialization. Actually, only five out of 139 plant species (3.6\%) in this novel community have a known history of invading natural communities, namely Japanese Honeysuckle (Lonicera japonica), Calla lily 
(Zantedeschia aethiopica), West-Indian Lantana (Lantana camara), Bigleaf hydrangea (Hydrangea macrophylla), and Bermuda buttercup (Oxalis pes-caprae), and only the latter has shown invasive behaviour in Portugal mainland as an early-successional invader of disturbed grounds (Marchante et al. 2014). Logically, the successful integration of alien plants in their recipient communities is dictated by the specific traits that mediate their capacity to compete for pollinators, naturalize, and eventually spread (Razanajatovo et al. 2015; Hui et al. 2016). This distinction between invasive and non-invasive alien plants thus marks a very important difference between this study and the dominant literature on the impact of biological invasions. The virtual lack of invasive species in the botanical garden of the University of Coimbra prevents from formally contrasting the visitation patterns of invasive and non-invasive aliens; however, this should be taken into account in future studies.

In the current scenario of accelerating biotic homogenization, most introduced species are not invasive and it is vital to know to what extent they can act as functional surrogates of native vegetation, to fully understand the longterm effects of homogenisation (Olden et al. 2006). Here we failed to detect structural differences in pollination networks as a result of the incorporation of alien plant species, even when the community was almost exclusively formed by alien plants. Clearly, it is too early for generalizations, and future studies of highly artificial communities (such as those from urban environments) will be highly valuable to validate these trends. Similarly, it remains to be tested if these novel interactions are as effective as native ones in promoting pollen deposition and effective pollination (Morton and Rafferty 2017). There is an increasing and well-justified interest in understanding the functioning of highly disturbed ecosystems, leading to new research fronts such as urban ecology and taxon substitutions (Hansen et al. 2010). We are, therefore, largely optimistic that the implementation of network studies and the use of botanical gardens as experimental grounds for the effects novel biological contexts will continue to shed light into some of the central theorems of ecology, including community assembly rules, and informing conservation efforts in an increasingly homogenized world.

Acknowledgements We would like to thank Carine Azevedo, Arménio Matos, Filipe Covelo and Kathryn Dix for their valuable assistance with pollination sampling and plant identifications. This work was financed by Fundação para Ciência e Tecnologia/Ministério da Educação e Ciência through national funds and co-funded by the European Regional Development Fund-FEDER, within the Portugal 2020 Partnership Agreement, and the Operational Thematic Program for Competitiveness and Internationalization-COMPETE 2020, namely through project UID/BIA/04004/2013, and grants SFRH/BD/130942/2017 (FLN), SFRH/BD/96292/2013 (JMC), and IF/00441/2013 (RHH). The Botanic Garden of the University of Coimbra is part of PRISC - Portuguese Research Infrastructure of Scientific Collections (POCI-01-0145-FEDER-022168).
Author contribution statement $\mathrm{RHH}$ and AG designed the study. CO, FL-N and JMC collected the data. ST and CO performed the analysis and lead the writing with substantial contributions of all authors to discussions and revisions.

\section{Compliance with ethical standards}

Conflict of interest The authors declare that they have no conflict of interest.

\section{References}

Aizen MA, Morales CL, Morales JM (2008) Invasive mutualists erode native pollination webs. PLoS Biol 6:e31. https://doi.org/10.1371/ journal.pbio.0060031

Albrecht M, Padron B, Bartomeus I, Traveset A (2014) Consequences of plant invasions on compartmentalization and species' roles in plant-pollinator networks. Proc R Soc B Biol Sci 281:20140773. https://doi.org/10.1098/rspb.2014.0773

Barnosky AD, Hadly EA, Bascompte J, Berlow EL, Brown JH, Fortelius M, Getz WM, Harte J, Hastings A, Marquet PA et al (2012) Approaching a state shift in Earth/'s biosphere. Nature 486:52-58. https://doi.org/10.1038/nature11018

Bartomeus I, Vilà M, Santamaría L (2008) Contrasting effects of invasive plants in plant-pollinator networks. Oecologia 155:761-770. https://doi.org/10.1007/s00442-007-0946-1

Blüthgen N, Menzel F, Blüthgen N (2006) Measuring specialization in species interaction networks. BMC Ecol 6:9. https://doi. org/10.1186/1472-6785-6-9

Cantoni E, Ronchetti E (2001) Robust inference for generalized linear models. J Am Stat Assoc 96:1022-1030. https://doi. org/10.1198/016214501753209004

Cantoni E, Ronchetti E (2006) A robust approach for skewed and heavy-tailed outcomes in the analysis of health care expenditures. J Health Econ 25:198-213. https://doi.org/10.1016/j.jheal eco.2005.04.010

Carvalheiro LG, Barbosa ERM, Memmott J (2008) Pollinator networks, alien species and the conservation of rare plants: trinia glauca as a case study. J Appl Ecol 45:1419-1427

Castro-Urgal R, Tur C, Albrecht M, Traveset A (2012) How different link weights affect the structure of quantitative flower-visitation networks. Basic Appl Ecol 13:500-508. https://doi.org/10.1016/j. baae.2012.08.002

Chittka L, Schürkens S (2001) Successful invasion of a floral market. Nature 411:653. https://doi.org/10.1038/35079676

Costa JM, da Silva LP, Ramos JA, Heleno RH (2015) Sampling completeness in seed dispersal networks: when enough is enough. Basic Appl Ecol. https://doi.org/10.1016/j.baae.2015.09.008

Cox B (2001) The biogeographic regions reconsidered. J Biogeogr 28:511-523. https://doi.org/10.1046/j.1365-2699.2001.00566.X

de Buffon G-LL (1761) Histoire naturelle générale et particulière. L'Imprimerie de F. Dufart, Paris

Devictor V, Clavel J, Julliard R, Lavergne S, Mouillot D, Thuiller W, Venail P, Villéger S, Mouquet N (2010) Defining and measuring ecological specialization. J Appl Ecol 47:15-25. https://doi.org/ 10.1111/j.1365-2664.2009.01744.x

Dormann CF (2011) How to be a specialist? Quantifying specialisation in pollination networks. Netw Biol 1:1-20

Dormann CF, Gruber B, Fründ J (2008) Introducing the bipartite package: analysing ecological networks. R News 8:8-11

Dormann CF, Fründ J, Bluthgen N, Gruber B (2009) Indices, graphs and null models: analysing bipartite ecological networks. Open Ecol J 2:7-24. https://doi.org/10.2174/1874213000902010007 
Dormann CF, Fründ J, Schaefer HM (2017) Identifying causes of patterns in ecological networks: opportunities and limitations. Annu Rev Ecol Evol Syst 48:559-584. https://doi.org/10.1146/annur ev-ecolsys-110316-022928

Fründ J, McCann KS, Williams NM (2016) Sampling bias is a challenge for quantifying specialization and network structure: lessons from a quantitative niche model. Oikos 125:502-513. https://doi. org/10.1111/oik.02256

Galeano J, Pastor JM, Iriondo JM (2009) weighted-interaction nestedness estimator (WINE): a new estimator to calculate over frequency matrices. Environ Model Softw 24:1342-1346. https:// doi.org/10.1016/j.envsoft.2009.05.014

GBIF (2017) GBIF: the global biodiversity information facility.https:// www.gbif.org/what-is-gbif. Accessed 28 Dec 2017

Grass I, Berens DG, Peter F, Farwig N (2013) Additive effects of exotic plant abundance and land-use intensity on plant-pollinator interactions. Oecologia 173:913-923. https://doi.org/10.1007/s0044 2-013-2688-6

Hansen DM, Donlan CJ, Griffiths CJ, Campbell KJ (2010) Ecological history and latent conservation potential: large and giant tortoises as a model for taxon substitutions. Ecography 33:272-284. https ://doi.org/10.1111/j.1600-0587.2010.06305.x

Heleno RH, Ceia RS, Ramos JA, Memmott J (2009) Effects of alien plants on insect abundance and biomass: a food-web approach. Conserv Biol 23:410-419. https://doi.org/10.111 1/j.1523-1739.2008.01129.x

Heleno R, Garcia C, Jordano P, Traveset A, Gomez JM, Bluthgen N, Memmott J, Moora M, Cerdeira J, Rodriguez-Echeverria S, Freitas H, Olesen JM (2014) Ecological networks: delving into the architecture of biodiversity. Biol Let 10:20131000. https://doi. org/10.1098/rsbl.2013.1000

Hobbs RJ, Arico S, Aronson J, Baron JS, Bridgewater P, Cramer VA, Epstein PR, Ewel JJ, Klink CA, Lugo AE, Norton D, Ojima D, Richardson DM, Sanderson EW, Valladares F, Vila M, Zamora R, Zobel M (2006) Novel ecosystems: theoretical and management aspects of the new ecological world order. Glob Ecol Biogeogr 15:1-7. https://doi.org/10.1111/j.1466-822X.2006.00212.x

Hothorn T, Bretz F, Westfall P (2008) Simultaneous inference in general parametric models. Biom J 50:346-363

Hui C, Richardson DM, Landi P, Minoarivelo HO, Garnas J, Roy HE (2016) Defining invasiveness and invasibility in ecological networks. Biol Invasions 18:971-983. https://doi.org/10.1007/s1053 0-016-1076-7

Kaiser-Bunbury CN, Valentin T, Mougal J, Matatiken D, Ghazoul J (2011) The tolerance of island plant-pollinator networks to alien plants. J Ecol 99:202-213. https://doi.org/10.111 1/j.1365-2745.2010.01732.x

Kaiser-Bunbury CN, Mougal J, Whittington AE, Valentin T, Gabriel R, Olesen JM, Blüthgen N (2017) Ecosystem restoration strengthens pollination network resilience and function. Nature 542:223-227. https://doi.org/10.1038/nature21071

Le Roux JJ, Hui C, Keet JH, Ellis AG (2017) Co-introduction vs ecological fitting as pathways to the establishment of effective mutualisms during biological invasions. New Phytol 215:1354-1360. https://doi.org/10.1111/nph.14593

Lopezaraiza-Mikel ME, Hayes RB, Whalley MR, Memmott J (2007) The impact of an alien plant on a native plant-pollinator network: an experimental approach. Ecol Lett 10:539-550. https://doi.org /10.1111/j.1461-0248.2007.01055.x

López-Núñez FA, Heleno RH, Ribeiro S, Marchante H, Marchante E (2017) Four-trophic level food webs reveal the cascading impacts of an invasive plant targeted for biocontrol. Ecology 98:782-793. https://doi.org/10.1002/ecy.1701

Lurgi M, Lopez BC, Montoya JM (2012) Novel communities from climate change. Philos Trans R Soc B Biol Sci 367:2913-2922. https://doi.org/10.1098/rstb.2012.0238
Marchante H, Morais M, Freitas H, Marchante E (2014) Guia prático para a identificação de plantas invasoras em Portugal. Imprensa da Universidade de Coimbra, Coimbra

McKinney ML, Lockwood JL (1999) Biotic homogenization: a few winners replacing many losers in the next mass extinction. Trends Ecol Evol 14:450-453. https://doi.org/10.1016/S0169 -5347(99)01679-1

Memmott J, Waser NM (2002) Integration of alien plants into a native flower-pollinator visitation web. Proc R Soc B: Biol Sci 269:2395-2399. https://doi.org/10.1098/rspb.2002.2174

Memmott J, Waser NM, Price MV (2004) Tolerance of pollination networks to species extinctions. Proc R Soc B Biol Sci 271:2605-2611. https://doi.org/10.1098/rspb.2004.2909

Morales CL, Aizen MA (2006) Invasive mutualisms and the structure of plant-pollinator interactions in the temperate forests of north-west Patagonia, Argentina. J Ecol 94:171-180. https:// doi.org/10.1111/j.1365-2745.2005.01069.x

Morton EM, Rafferty NE (2017) Plant-pollinator interactions under climate change: the use of spatial and temporal transplants. Appl Plant Sci 5:1600133. https://doi.org/10.3732/apps.16001 33

Olden JD, Poff NL, McKinney ML (2006) Forecasting faunal and floral homogenization associated with human population geography in North America. Biol Cons 127:261-271. https://doi.org/10.1016/j. biocon.2005.04.027

Padrón B, Traveset A, Biedenweg T, Díaz D, Nogales M, Olesen JM (2009) Impact of alien plant invaders on pollination networks in two archipelagos. PLoS ONE. https://doi.org/10.1371/journ al.pone. 0006275

Patefield WM (1981) Algorithm AS 159: an Efficient Method of Generating Random $\mathrm{R} \times \mathrm{C}$ Tables with Given Row and Column Totals. Appl Stat 30:91-97. https://doi.org/10.2307/2346669

Potts SG, Biesmeijer JC, Kremen C, Neumann P, Schweiger O, Kunin WE (2010) Global pollinator declines: trends, impacts and drivers. Trends Ecol Evol 25:345-353. https://doi.org/10.1016/j. tree.2010.01.007

Primack RB, Miller-Rushing AJ (2009) The role of botanical gardens in climate change research. New Phytol 182:303-313. https://doi. org/10.1111/j.1469-8137.2009.02800.x

R Core Team (2017) R: A language and environment for statistical computing. R Foundation for Statistical Computing, Vienna, Austria. https://www.R-project.org/

Razanajatovo M, Föhr C, Fischer M, Prati D, van Kleunen M (2015) Non-naturalized alien plants receive fewer flower visits than naturalized and native plants in a Swiss botanical garden. Biol Cons 182:109-116. https://doi.org/10.1016/j.biocon.2014.11.043

Razanajatovo M, Föhr C, van Kleunen M, Fischer M (2018) Phenological shifts and flower visitation of 185 lowland and alpine species in a lowland botanical garden. Alpine Bot. https://doi.org/10.1007/ s00035-018-0201-x

Richardson DM (2010) Fifty years of invasion ecology. Wiley-Blackwell, Oxford

Richardson DM, Allsopp N, D’Antonio CM, Milton SJ, Rejmánek M (2000a) Plant invasions-the role of mutualisms. Biol Rev 75:65-93

Richardson DM, Pyšek P, Rejmánek M, Barbour MG, Dane Panetta F, West CJ (2000b) Naturalization and invasion of alien plants: concepts and definitions. Divers Distrib 6:93-107. https://doi.org /10.1046/j.1472-4642.2000.00083.x

Rousseeuw P, Croux C, Todorov V, Ruckstuhl A, Salibian-Barrera M, Verbeke T, Koller M, Concieção E, di Palma MA (2017) Robustbase: basic robust statistics $\mathrm{R}$ package version 0.92-8. 169

Rumeu B, Devoto M, Traveset A, Olesen JM, Vargas P, Nogales M, Heleno R (2017) Predicting the consequences of disperser extinction: richness matters the most when abundance is low. Funct Ecol. https://doi.org/10.1111/1365-2435.12897 
Schleuning M, Fründ J, Klein A-M, Abrahamczyk S, Alarcón R, Albrecht M, Andersson GKS, Bazarian S, Böhning-Gaese K, Bommarco R, Dalsgaard B, Dehling DM, Gotlieb A, Hagen M, Hickler T, Holzschuh A, Kaiser-Bunbury CN, Kreft H, Morris RJ, Sandel B, Sutherland WJ, Svenning J-C, Tscharntke T, Watts S, Weiner CN, Werner M, Williams NM, Winqvist C, Dormann CF, Blüthgen N (2012) Specialization of mutualistic interaction networks decreases toward tropical latitudes. Curr Biol 22:1925-1931. https ://doi.org/10.1016/j.cub.2012.08.015

Smart SM, Thompson K, Marrs RH, Le Duc MG, Maskell LC, Firbank LG (2006) Biotic homogenization and changes in species diversity across human-modified ecosystems. Proc Biol Sci 273:26592665. https://doi.org/10.1098/rspb.2006.3630

Stouffer DB, Cirtwill AR, Bascompte J (2014) How exotic plants integrate into pollination networks. J Ecol 102:1442-1450. https:// doi.org/10.1111/1365-2745.12310

Thebault E, Fontaine C (2010) Stability of ecological communities and the architecture of mutualistic and trophic networks. Science 329:853-856. https://doi.org/10.1126/science.1188321

Traveset A, Richardson DM (2006) Biological invasions as disruptors of plant reproductive mutualisms. Trends Ecol Evol 21:208-216. https://doi.org/10.1016/J.TREE.2006.01.006

Traveset A, Heleno R, Chamorro S, Vargas P, McMullen CK, CastroUrgal R, Nogales M, Herrera HW, Olesen JM (2013) Invaders of pollination networks in the Galapagos Islands: emergence of novel communities. Proc R Soc B Biol Sci 280:20123040. https://doi. org/10.1098/rspb.2012.3040

Traveset A, Tur C, Trøjelsgaard K, Heleno R, Castro-Urgal R, Olesen JM (2016) Global patterns of mainland and insular pollination networks. Glob Ecol Biogeogr 25:880-890. https://doi.org/10.1111/ geb.12362

Tylianakis JM, Morris RJ (2017) Ecological networks across environmental gradients. Annu Rev Ecol Evol Syst 48:25-48. https://doi. org/10.1146/annurev-ecolsys-110316-022821

Tylianakis JM, Tscharntke T, Lewis OT (2007) Habitat modification alters the structure of tropical host-parasitoid food webs. Nature 445:202-205. https://doi.org/10.1038/nature05429 van Kleunen M, Essl F, Pergl J, Brundu G, Carboni M, Dullinger S, Early R, González-Moreno P, Groom QJ, Hulme PE, Kueffer C, Kühn I, Máguas C, Maurel N, Novoa A, Parepa M, Pyšek P, Seebens H, Tanner R, Touza J, Verbrugge L, Weber E, Dawson W, Kreft H, Weigelt P, Winter M, Klonner G, Talluto MV, DehnenSchmutz K (2018) The changing role of ornamental horticulture in alien plant invasions. Biol Rev 93:1421-1437. https://doi. org/10.1111/brv.12402

Vander Zanden MJ (2005) The success of animal invaders. Proc Natl Acad Sci 102:7055-7056. https://doi.org/10.1073/pnas.05025 49102

Vilà M, Bartomeus I, Dietzsch AC, Petanidou T, Steffan-Dewenter I, Stout JC, Tscheulin T (2009) Invasive plant integration into native plant-pollinator networks across Europe. Proc Biol Sci 276:3887-3893. https://doi.org/10.1098/rspb.2009.1076

Vilà M, Basnou C, Pyšek P, Josefsson M, Genovesi P, Gollasch S, Nentwig W, Olenin S, Roques A, Roy D, Hulme PE, Andriopoulos P, Arianoutsou M, Bazos I, Kokkoris I, Yannitsaros A, Zikos A, Augustin S, Cochard PO, Lopez-Vaamonde C, Sauvard D, Yart A, Bacher S, Bretagnolle F, Gasquez J, Chiron F, Kark S, Shirley S, Clergeau P, Cocquempot C, Coeur d'Acier A, Dorkeld F, Migeon A, Navajas M, David M, Delipetrou P, Georghiou K, DesprezLoustau ML, Didziulis V, Essl F, Galil BS, Hedja M, Jarosik V, Pergl J, Perglová I, Kühn I, Winter M, Kühn PW, Marcer A, Pino J, McLoughlin M, Minchin D, Panov VE, Pascal M, Poboljsaj K, Scalera R, Sedlácek O, Zagatti P (2010) How well do we understand the impacts of alien species on ecosystem services? A panEuropean, cross-taxa assessment. Front Ecol Environ 8:135-144. https://doi.org/10.1890/080083

von Humboldt A (1816) Sur les lois que l'on observe dans la distribution des formes vegetales. Ann Chim Phys 1:225-239

WCSP (2017) World checklist of selected plant families. Facilitated by the Royal Botanic Gardens, Kew. http://wcsp.science.kew.org/. Accessed 28 Dec 2017

Williamson M (1993) Invaders, weeds and the risk from genetically manipulated organisms. Experientia 49:219-224. https://doi. org/10.1007/BF01923529 
Pollination networks from natural, and anthropogenic-novel communities show high structural similarity

Sérgio Timóteo ${ }^{1}$, Catherine J. O’Connor, Francisco A. López-Núñez, José M. Costa, António C. Gouveia, Ruben H. Heleno

${ }^{1}$ Corresponding author:

Sérgio Timóteo; Centre for Functional Ecology (CFE-UC), Department of Life Sciences, University of Coimbra, Portugal; stimoteo@gmail.com 


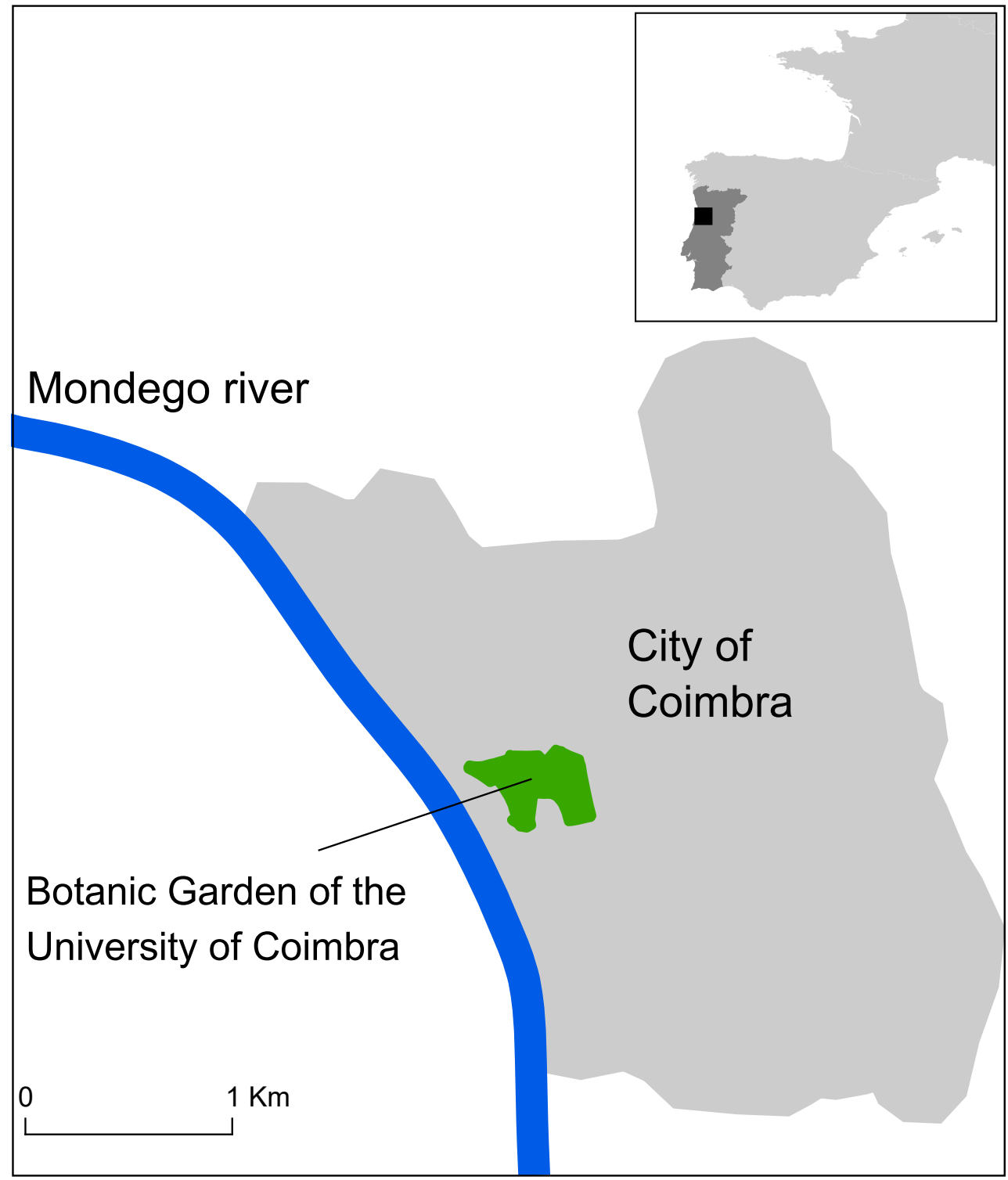

Fig. S1 Location of the Botanic Garden of the University of Coimbra, within the regional and local urban context. 


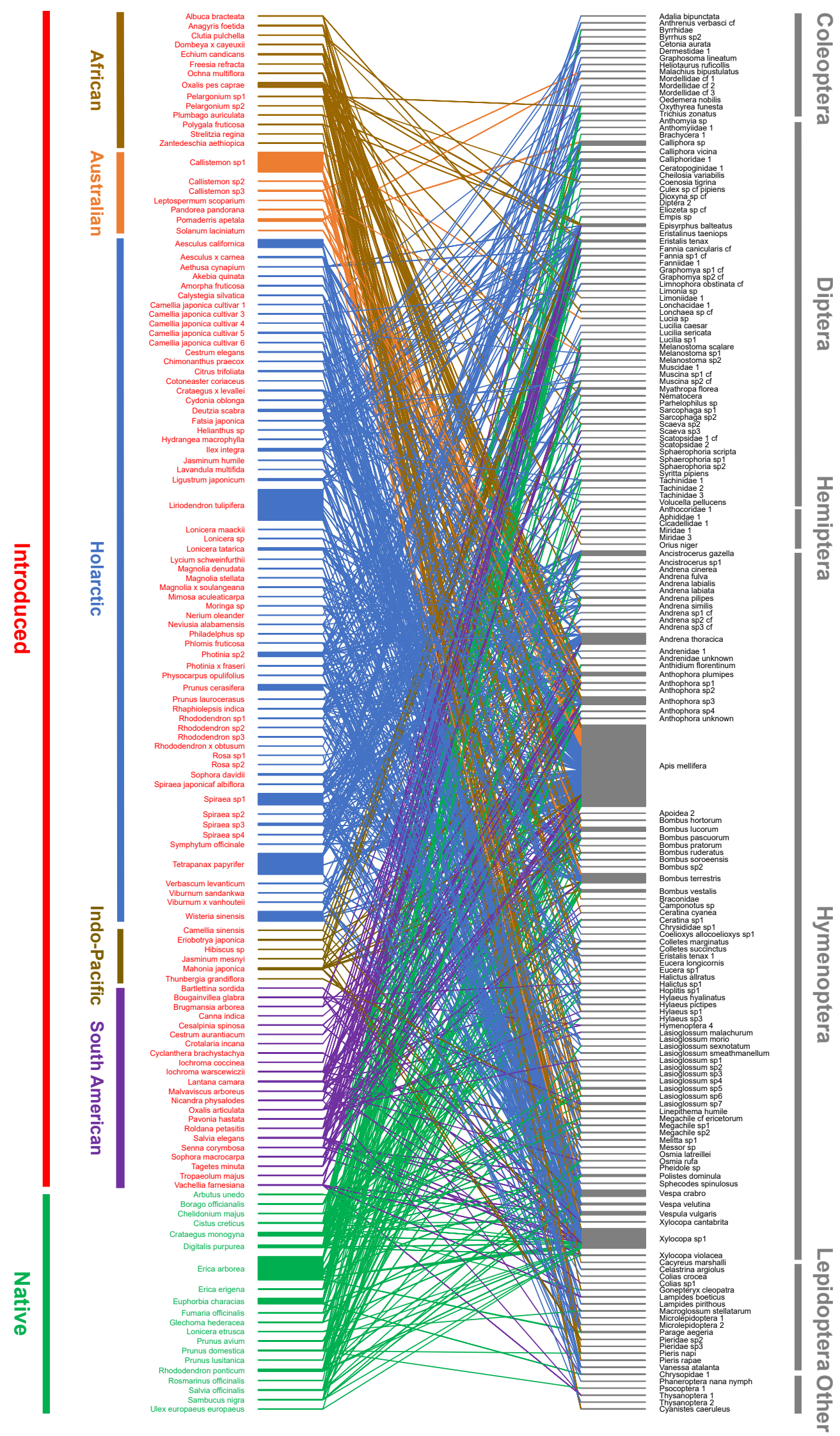

Fig. S2 Quantitative plant visitation network of the Botanical Garden of the University of Coimbra, Portugal, including the identification of plants and flower visitors. The network represents the interactions between 176 pollinators and 132 plant species and the width of each interaction is proportional to the number of visits/flower/minute. Network based on a total effort of 255 hours of direct observations to flowers between November 2016 and May 2017. 


\section{Supplementary references}

Aizen MA, Morales CL, Morales JM (2008) Invasive mutualists erode native pollination webs. PLoS Biol 6:e31.

Bartomeus I, Vilà M, Santamaría L (2008) Contrasting effects of invasive plants in plant-pollinator networks. Oecologia 155:761-770. doi: 10.1007/s00442-007-0946-1

Benadi G, Blüthgen N, Hovestadt T, Poethke H-J (2013) When can plant-pollinator interactions promote plant diversity? Am Nat 182:131-146. doi: 10.1086/670942

Carvalheiro LG, Barbosa ERM, Memmott J (2008) Pollinator networks, alien species and the conservation of rare plants: Trinia glauca as a case study. J Appl Ecol 45:1419-1427.

Castro-Urgal R, Traveset A (2014) Differences in flower visitation networks between an oceanic and a continental island. Bot J Linn Soc 174:478-488. doi: 10.1111/boj.12134

Devoto M, Bailey S, Craze P, Memmott J (2012) Understanding and planning ecological restoration of plant-pollinator networks. Ecol Lett 319-328. doi: 10.1111/j.1461-0248.2012.01740.x

Dicks L V., Corbet SA, Pywell RF (2002) Compartmentalization in plant-insect flower visitor webs. J Anim Ecol 71:32-43. doi: 10.1046/j.0021-8790.2001.00572.x

Elberling H, Olesen JM (1999) The structure of a high latitude plant-flower visitor system: the dominance of flies. Ecography (Cop) 22:314-323. doi: 10.1111/j.1600-0587.1999.tb00507.x

Hocking B (1968) Insect-flower associations in the high arctic with special reference to nectar. Oikos 19:359. doi: 10.2307/3565022

Ingversen TT (2006) Plant-pollinator interactions on Jamaica and Dominica. Aarhus University, Aarhus, Denmark

Inouye DW, Pyke GH (1988) Pollination biology in the Snowy Mountains of Australia: Comparisons with montane Colorado, USA. Austral Ecol 13:191-205. doi: 10.1111/j.1442-9993.1988.tb00968.x

Johansson A "Sixten" (2012) A plant-pollinator network on Fårö island: description, comparison and general patterns. Gotland University, Sweden

Junker RR, Blüthgen N, Brehm T, et al (2013) Specialization on traits as basis for the niche-breadth of flower visitors and as structuring mechanism of ecological networks. Funct Ecol 27:329-341. doi: 10.1111/1365-2435.12005

Kaiser-Bunbury CN, Memmott J, Müller CB (2009) Community structure of pollination webs of Mauritian heathland habitats. Perspect Plant Ecol Evol Syst 11:241-254. doi:

10.1016/j.ppees.2009.04.001

Kakutani T, Inoue T, Kato M, Ichihashi H (1990) Insect-flower relationship in the campus of Kyoto University, Kyoto: an overview of the flowering phenology and the seasonal pattern of insect visits. Contrib from Biol Lab Kyoto Univ 27:465-522.

Kato M (2000) Anthophilous insect community and plant-pollinator interactions on Amami Islands in the Ryukyu Archipelago, Japan. Contrib from Biol Lab Kyoto Univ 29:157-254. 
Kato M, Matsumoto M, Kato T (1993) Flowering phenology and anthophilous insect community in the cool-temperate subalpine forests and meadows at Mt. Kushigata in the central part of Japan. Contrib from Biol Lab Kyoto Univ 28:119-172.

Kato M, Miura R (1996) Flowering phenology and anthophilous insect community at a threatened natural lowland marsh at Nakaikemi in Tsuruga, Japan. Contrib from Biol Lab Kyoto Univ 29:1-48.

Kevan PG (1970) High Artic insect-flower relations: the inter-relationship of arthropods and flowers at Lake Hazen, Ellesmere Island, N.W.T., Canada. University of Alberta, Edmonton, Alberta, Canada

Lopezaraiza-Mikel ME, Hayes RB, Whalley MR, Memmott J (2007) The impact of an alien plant on a native plant-pollinator network: an experimental approach. Ecol Lett 10:539-50. doi:

10.1111/j.1461-0248.2007.01055.x

Lundgren R, Olesen JM (2005) The dense and highly connected world of Greenland's plants and their pollinators. Arctic, Antarct Alp Res 37:514-520. doi: 10.2307/4095870

Memmott J (1999) The structure of a plant pollinator food web. Ecol Lett 2:276-280.

Mosquin T, Martin JEH (1967) Observation on the pollination biology of plants on Melville Island, N.W.T., Canada. Can F Nat 81:201-205.

Motten AF (1986) Pollination ecology of the spring wildflower community of a temperate deciduous forest. Ecol Monogr 56:21-42. doi: 10.2307/2937269

Olesen JM, Eskildsen LI, Venkatasamy S (2002) Invasion of pollination networks on oceanic islands: importance of invader complexes and endemic super generalists. Divers $<$ html_ent glyph=“@amp;" ascii="\&amp;"/> Distrib 8:181-192. doi: 10.1046/j.1472-4642.2002.00148.x

Pocock MJO, Evans DM, Memmott J (2012) The robustness and restoration of a network of ecological networks. Science 335:973-977. doi: 10.1126/science.1214915

Small E (1982) Insect pollinators of the Mer Bleue peat bog of Ottawa. Can F Nat 90:22-28.

Traveset A, Heleno R, Chamorro S, et al (2013) Invaders of pollination networks in the Galápagos Islands: emergence of novel communities.

Trøjelsgaard K, Jordano P, Carstensen DW, Olesen JM (2015) Geographical variation in mutualistic networks: similarity, turnover and partner fidelity. Proc R Soc B Biol Sci 282:20142925-20142925. doi: $10.1098 /$ rspb.2014.2925

Tur C (2015) Plant-pollinator networks: incorporating individual variation and functional information. Universitat de les Illes Balears, Palma de Maiorca, Spain

Vázquez DP, Simberloff D (2002) Ecological specialization and susceptibility to disturbance: Conjectures and refutations. Am Nat 159:606-623.

Wallin J (2011) Plant-pollinator networks in three habitats on a Baltic Island. Gotland University, Sweden 
Yamazaki K, Kato M (2003) Flowering phenology and anthophilous insect community in a grassland ecosystem at Mt. Yufu, Western Japan. Contrib from Biol Lab Kyoto Univ 29:255-318. 